https://doi.org/10.31470/2706-7904-2020-15-142-145

\title{
ПСИХОЛІНГВІСТИЧНИЙ АНАЛІЗ ІНТЕНЦЙ ГЕРМЕНЕВТИКИ В ДИСКУРСІ ЕПІСТЕМОЛОГІї
}

\author{
Psycholinguistic Analysis of the Intention of Hermeneutics \\ in the Discourse of Epistemology
}

\author{
Vasyl Kremen \\ DSc. in Philosophy, Professor \\ National Academy of Educational Sciences of Ukraine \\ president@naps.gov.ua \\ https://orcid.org/0000-0001-5459-1318

\section{Volodymyr Ilyin} \\ DSc. in Philosophy, Professor \\ Taras Shevchenko National University of Kyiv (Ukraine) \\ ilinvv@ukr.net \\ https://orcid.org/0000-0001-9107-0829
}

\begin{abstract}
The article is devoted to the psycholinguistic analysis of modern epistemology which provide new formats of interaction between «word» and «vision», and also determine the correlation between language and thought. The purpose of the study is to substantiate theoretically the use of psycholinguistic methods as a new format of modern epistemological discourses based on hermeneutics, cognitivism, and psychology of perception and its modifications as well.

Theoretical analysis has shown the importance of hermeneutic interpretation of texts, where a person through psychological contemplation and pre-logical, pre-reflective, pre-conceptual experience opens new horizons of knowledge about the world and himself. Language as the "house of being» is a psycholinguistic sphere that determines the transition from the general structures of consciousness to its psychosemantic correlation with the essential content of knowledge.
\end{abstract}

Key words: psycholinguistics; verbal; perception; language; epistemology.

\section{Вступ \\ Introduction}

Розвиток нових аспектів епістемології в останні десятиліття суттєво розширив простір психолінгвістичного аналізу, як продуктивного способу мовної обробки 
нових понять і дискурсів. Взаємодіючи з психічними, семантичними, перцептивними процесами, які визначають співвідношення між мовою і свідомістю, вербальним i візуальним, вони допомагають зрозуміти процес презентації i засвоєння слова, речення, смисл знання в процесах інтелектуальної діяльності і багатоманітності когнітивних практик. У контексті такого підходу психолінгвістика стає невід’ємною частиною сучасної епістемології, в якій поряд з мовою як «досвідом світу» все більше впроваджуються матеріали герменевтичних практик.

\section{Методи та методики дослідження}

\section{Methods and Techniques of the Research}

Для реалізації визначення мети дослідження психолінгвістичного аспекту в сучасному епістемологічному дискурсі були використані герменевтичні i феноменологічні когнітивні практики, які включають очевидність, інтенціональність, семантику, темпоральність. Методологія семантичної метамови, яка визнає антропоцентричність категоризації об’єктів і явищ світу, мови в цілому, в якій представлена також психологія суб'єкта мовлення, дозволила співставити і поєднати системи сприйняття і системи слова. Для виявлення психолінгвістичної структури мовного образу застосовувався міждисциплінарний підхід, метод порівняльного аналізу, метод екстраполяції. В своєму взаємозв'язку вони стимулюють розвиток і конкретизацію психолінгвістичних знань, психолінгвістичних досліджень сприйняття, психолінгвістичного пояснення складних взаємодій візуального, когнітивного, вербального, інтелектуального.

\section{Результати \\ Results}

У контексті психолінгвістичного аналізу для сучасної епістемології важливим і значущим є герменевтичний підхід до мови, який визначає їі роль в пізнанні. Не тільки на рівні понять і речень, але і як «універсальне середовище», «горизонт онтології», де людина через систему самоаналізу, внутрішнього споглядання пізнає себе і свою сутність. Якщо епістемологія прагне стати продуктивною, орієнтуватися на цілісну, «живу» людину в єдності ії чуттів, мислення, волі, свідомості, віри, емоцій, потрібно врахувати досвід герменевтики i дотичних до неї філософії життя, екзистенціалізму, феноменології. Пізнання, як правило, поряд 3 експериментами i дослідами, має справу з мовою, символами, текстами, контекстами. Проблема полягає в 
розкритті семантичного змісту знання і осягненні його значення для людини, що передбачає звернення до внутрішнього, психологічного досвіду як психолінгвістичної сфери.

Цей досвід засвідчує, що в процесі своєї інтелектуально-пізнавальної діяльності людина досить часто говорить і здійснює вчинки поза свідомим контролем, без попередньої рефлексії. Дана обставина дозволяє говорити про мову, яка згідно концепції «герменевтичної інтерпретації» М. Гайдеггера постає в якості психологічного інструменту проникнення в семантичну сутність текстів, є «домом буття» і способом його «опитування» (Хайдеггер, 2003). Тим самим здійснюється перехід від загальних структур свідомості самих по собі до психолінгвістичного і семантичного зв’язку свідомості зі світом, через яку «говорить», вступає в обмін словами, сам світ.

Для розуміння фундаментальної проблеми взаємовідношення епістемології і мови, що розглядаються переважно в пізнавальному контексті, важливою є ідея первинності мови. Це - артикуляція розуміння, яке передує тлумаченню i висловлюванням. Характеристика мови як «здійснюваного буття» $\epsilon$ не лише лінгвістичне, а й герменевтичне звернення до неї. Воно передбачає «почути», як в мові «говорить саме буття» (Хайдеггер, 1993).

Істина постає оприявленням сутності. Пізнання не творить «світ», а лише розкриває його. Проникнення ж в сутність відбувається через мову. Психолінгвісти вивчають процес перетворення речень і смислу слів для представлення в розумі, як слова формуються в процесі мовлення в речення і смислові тексти. В цьому контексті психолінгвістичний зміст мовних процесів на шляху перетворення їх в продуктивне мислення має епістемологічний характер.

\section{Висновки \\ Conclusions}

Теоретичне обгрунтування необхідності включення психолінгвістичного аналізу до парадигми сучасної епістемології відкриває нові перспективи в когнітивістиці, сприйнятті, логічному і семантичному дослідженнях. Продуктивність епістемології обумовлена орієнтацією на метод герменевтичної інтерпретації, яка має справу з мовою, символами, текстами, контекстами, знаковими системами. Розкриття їх смислу передбачає звернення до внутрішнього, психологічного досвіду, який у взаємодії вербального та візуального відкриває можливості зрозуміти смисли об'єктів пізнання. Міждисциплінарність епістемологічних дискурсів вписується в технологічні i наукові досягнення інформаційного світу. Його нові образи розширюють психологічне, когнітивне сприйняття, утворюючи нову реальність. На 
Psycholinguistics in a Modern World - 2020. Proceedings of the 15th International Scientific and Practical Conference (Pereiaslav-Khmelnytskyi, 22-23 October, 2020)

основі ऑiі психолінгвістичного аналізу виникає можливість одержання нового епістемологічного досвіду, який утворює інший характер практичних взаємодій в контексті нових когнітивних, вербальних, культурних смислів.

\section{Лiтература}

References

Хайдеггер, М. (1993). Время и бытие: Статьи и выступления. Москва: Республика.

Хайдеггер, М. (2003). Бытие и время. Харьков: «Фолио». 